\title{
Analisis Penyampaian SPT Masa dan Jumlah Wajib Pajak Badan Dalam Meningkatkan Penerimaan Pajak Penghasilan Pasal 21 di KPP Pratama Medan Belawan
}

\author{
Zulia Hanum \\ Fakultas Ekonomi dan Bisnis Universitas Muhammadiyah Sumatera Utara \\ Jl. Kapten Mukhtar Basri No. 3 Medan 20238 \\ zuliahanum@umsu.ac.id
}

\begin{abstract}
ABSTRAK
Penelitian ini bertujuan untuk menganalisis penyampaian SPT Masa dan jumlah wajib pajak badan dalam meningkatkan penerimaan pajak di Kantor Pelayanan Pajak (KPP) Pratama Medan Belawan. Permasalahan yang terjadi di KPP Pratama Medan Belawan adalah wajib pajak badan yang menyampaikan SPT Masa tidak sebanding dengan jumlah wajib pajak badan yang terdaftar serta menurunnya penerimaan pajak. Metode penelitian yang digunakan adalah pendekatan deskriptif dan data yang diteliti dari tahun 2013 - 2016. Data diperoleh dari Seksi Pengolahan Data dan Informasi (Seksi PDI) KPP Pratama Medan Belawan. Teknik analisis data adalah analisis deskriptif, dimana data yang ada dikumpulkan kemudian dianalisis penyampaian SPT Masa dan jumlah wajib pajak badan dalam meningkatkan penerimaan pajak penghasilan Pasal 21 serta melakukan wawancara untuk mengetahui faktorfaktor yang menyebabkan penerimaan pajak tidak mencapai target dan upaya yang dilakukan agar penerimaan pajak meningkat di KPP Pratama Medan Belawan. Hasil analisis menunjukkan bahwa wajib pajak yang menyampaikan SPT Masa belum menunjukkan keseimbangan antara wajib pajak badan yang menyampaikan SPT Masa dan wajib pajak yang terdaftar di KPP Pratama Medan Belawan sehingga penerimaan pajak mengalami penurunan. Jadi KPP Pratama Medan Belawan perlu meningkatkan lagi kualitas pelayanan dan kualitas pengawasan terhadap wajib pajak badan dalam menyampaikan SPT Masa. KPP Pratama Medan Belawan harus lebih menggencarkan sosialisasi perpajakan terhadap wajib pajak agar kesadaran wajib pajak dalam menyamapaikan SPT Masa dan membayar pajak meningkat. Dengan diperbaikinya dari semua aspek diharapkan realisasi pajak yang diperoleh mencapai target pajak yang telah ditetapkan.
\end{abstract}

Kata Kunci : Penyampain SPT Masa, Wajib Pajak Badan, Penerimaan Pajak 


\title{
Analysis of Submission of Periodical Tax Returns and Total Corporate Taxpayers In Increasing Article 21 Income Tax Receipts at KPP Pratama Medan Belawan
}

\begin{abstract}
This study aims to analyze the submission of SPT Period and the number of corporate taxpayers in increasing tax revenues at the Medan Belawan Pratama Tax Service Office (KPP). The problems that occur in KPP Pratama Medan Belawan are taxpayers who submit period SPT not comparable with the number of registered corporate taxpayers and declining tax revenues. The research method used was a descriptive approach and the data examined from 2013 - 2016. Data was obtained from the Data and Information Processing Section (PDI Section) in Medan Belawan KPP. The data analysis technique is descriptive analysis, where the existing data is collected and then analyzed the submission of SPT Period and the number of corporate taxpayers in increasing the income of income tax Article 21 and conducting interviews to find out the factors that cause tax revenues not to reach the target and efforts made to receive tax increases at KPP Pratama Medan Belawan. The results of the analysis show that taxpayers who submit SPT Period have not shown a balance between the taxpayer of the entity that submits the Periodical Tax Returns and taxpayers registered at KPP Pratama Medan Belawan so that tax revenues decline. So KPP Pratama Medan Belawan needs to improve service quality and quality of supervision of corporate taxpayers in submitting SPT Period. Medan Belawan KPP Pratama must intensify taxation socialization for taxpayers so that taxpayers' awareness in providing period SPT and paying taxes increases. With repairs from all aspects expected the realization of the tax obtained reaches the predetermined tax target.
\end{abstract}

Keywords: Delivery of Periodic Tax Returns, Corporate Taxpayers, Tax Receipts 
Published December 2018

EKONOMIKAWAN : Jurnal Ilmu Ekonomi dan Studi Pembangunan

ISSN : 1693-7600 (Print), ISSN : 2598-0157 (Online), http://jurnal.umsu.ac.Id/Index.php/ekawan

\section{PENDAHULUAN}

Negara Republik Indonesia adalah negara hukum berdasarkan Pancasila dan Undang Undang 1945. Dimana setiap aspek tindakan pemerintah baik dalam lapangan pengaturan maupun lapangan pelayanan harus didasarkan pada peraturan perundang undangan serta dijiwai dengan pembangunan hukum nasional. Pembangunan hukum nasional adalah bagian dari pembangunan nasional yang perlu dilakukan secara berkesinambungan serta merata di seluruh tanah air yang tujuannya untuk meningkatkan kehidupan bangsa dan negara secara adil, makmur dan merata diseluruh kehidupan rakyat Indonesia. Kendala dana yang tidak sedikit merupakan salah satu hambatan yang mengganggu tercapainya tujuan pembangunan nasional. Pada Anggaran Penerimaan dan Belanja Negara (APBN), penerimaan dalam negeri yang terbesar adalah penerimaan dari pajak. Setiap tahunnya penerimaan pajak terus meningkat dan memberi andil yang besar dalam penerimaan negara.

Penerimaan negara dari pajak digunakan untuk membiayai pengeluaran rutin dan juga untuk membiayai pembangunan. Artinya, pembangunan dibiayai masyarakat. Oleh sebab itu upaya untuk meningkatkan penerimaan negara dari pajak sangatlah penting, Dana yang dihimpun berasal dari rakyat (private saving) atau berasal dari pemerintah (public saving). Dengan demikian, terlihat bahwa dari pajak terdapat sasaran yang dikehendaki adalah memberikan kesehjateraan masyarakat secara merata dengan melakukan pembangunan di berbagai sektor.

Pemerintah dalam hal ini kementerian keuangan melalui Direktorat Jenderal Pajak sangat mengapresiasi para wajib pajak, baik orang pribadi maupun badan-badan dalam bentuk perusahaan yang taat membayar pajak. Tetapi, sering juga ditemui pihak-pihak yang tidak memiliki kesadaran untuk membayar pajak.

Ada beberapa upaya telah dilakukan oleh pemerintah untuk meningkatkan penerimaan pajak yaitu dengan melakukan reformasi pajak, dimana tujuan utamanya adalah untuk lebih menegakkan kemandirian negara dalam membiayai pembangunan nasional dengan lebih mengarahkan segenap potensi dan kemampuan dari dalam negeri. Khususnya dengan cara meningkatkan penerimaan negara melalui perpajakan dari berbagai sumber diluar minyak bumi dan gas.

Reformasi perpajakan tahun 1983, sistem pemungutan pajak telah mengalami perubahan yang cukup signifikan yaitu dengan official assessment system menjadi self assessment system. Wajib pajak diberikan kepercayaan untuk menghitung, menyetor, dan melaporkan sendiri pajaknya yang terutang sendiri sesuai ketentuan peraturan perundangundangan perpajakan. Berdasarkan self assessment system, Wajib pajak orang pribadi yang menjalankan usaha atau pekerjaan bebas dan Wajib pajak badan, wajib mendaftarkan diri utuk memperoleh Nomor Pokok Wajib Pajak (NPWP) paling lama 1 bulan saat usaha mulai dijalankan. Nomor Pokok Wajib Pajak (NPWP) adalah nomor yang diberikan kepada wajib pajak sebagai sarana dalam administrasi perpajakan yang digunakan sebagai tanda pengenal diri atau identitas wajib pajak dalam melaksanakan hak dan kewajiban perpajakan sehingga NPWP merupakan kunci administrasi perpajakan. 


\section{Published December 2018}

EKONOMIKAWAN : Jurnal Ilmu Ekonomi dan Studi Pembangunan

ISSN : 1693-7600 (Print), ISSN : 2598-0157 (Online), http://jurnal.umsu.ac.id/index.php/ekawan

Sehingga penentuan besarnya pajak yang terutang dipercayakan pada wajib pajak sendiri melalui Surat Pemberitahuan (SPT) yang disampaikannya. Dengan sistem baru ini diharapkan partisipasi aktif dari masyarakat untuk memenuhi kewajiaban yang baik dan benar, dan administrasi perpajakan dapat dilaksanakan dengan rapi. Masyarakat yang memiliki penghasilan wajib mendaftarakan diri ke Kantor Pelayanaan Pajak (KPP) sesuai dengan peraturan perundang-undangan yang berlaku. Salah satu kewajiban wajib pajak terdaftar adalah membayar dan melaporkan pajak yang dikenakan sesuai peraturan yang berlaku.

Surat Pemberitahuan adalah sarana bagi wajib pajak untuk melaporkan seluruh kegiatan usahanya selama periode waktu tertentu. Selain itu, Surat Pemberitahuan (SPT) sebagai wujud pertanggungjawaban Wajib Pajak terhadap kinerja perusahaannya. Oleh karena itu, Surat Pemberitahuan (SPT) tidak hanya berfungsi sebagai data melainkan sarana komunikasi antara Wajib Pajak dengan fiskus untuk mempertanggung jawabkan pemenuhan seluruh kewajiban perpajakan perusahaan selama waktu tertentu. Penyampaian atau pelaporan Surat Pemberitahuan (SPT) masa yang dilakukan dengan teknologi dan prosedur yang memudahkan Wajib Pajak itu sendiri diharapkan meningkatkan penerimaan pajak penghasilan (PPH) Pasal 21.

Dalam penyampaian (Surat Pemberitahuan) SPT masa sangat menentukan tercapainya realisasi penerimaan pajak penghasilan $(\mathrm{PPh})$ pasal 21. Supaya prosedur pelaksanaan penyampaian SPT masa seperti pemotongan, penyetoran, pelaporan pajak atas penghasilan wajib pajak dapat dilakukan sebaik-baiknya, maka perlu ditetapkan ketentuan mengenai pelaksanaan pemotongan, penyetoran, pelaporan pajak penghasilan ( $\mathrm{PPh})$. SPT Masa harus dilapor setiap bulannya, jatuh tempo pelaporan adalah tanggal 20 bulan berikutnya. Gagal melaporkan akan berakibat denda sebesar Rp. 100.000,00. Menurut Iprianto dan Tarmidi (2014) dalam penyampaian SPT Masa sangat menentukan tercapainya realisasi penerimaan pajak penghasilan $(\mathrm{PPh})$ pasal 21.

Penerimaan dari sektor pajak terbagi menjadi dua golongan, yaitu dari pajak langsung misalnya pajak penghasilan dan pajak tidak langsung misalnyanya pajak pertambahan nilai. Jika dilihat dari segi penerimaan, pajak penghasilan dan pajak pertambahan nilai memiliki kontribusi yang tinggi untuk membantu negara dalam membiayai pengeluaran. Pajak Penghasilan Pasal 21 tidak semua orang dapat dikenakan pajak hanya dapat dikenakan kepada orang pribadi atau badan yang telah berpenghasilan diatas Penghasilan Tidak Kena Pajak (PTKP).

Undang Undang Pajak Penghasilan ( $\mathrm{PPh})$ mengatur pengenaan pajak penghasilan terhadap subjek pajak berkenaan dengan penghasilan yang diterima atau diperolehnya dalam tahun pajak. Subjek pajak tersebut dikenai pajak apabila menerima atau memperoleh penghasilan. Subjek Pajak yang menerima atau memperoleh penghasilan, dalam undang undang disebut Wajib Pajak.

Wajib pajak adalah orang pribadi atau badan yang menurut ketentuan peraturan perundang-undangan perpajakan ditentukan untuk melakukan kewajiban perpajakan, termasuk pemungut pajak atau pemotong pajak tertentu. Serta wajib pajak Penghasilan Pasal 21 adalah wajib pajak orang pribadi yang menerima penghasilan yang dipotong $\mathrm{PPh}$ pasal 21 . Wajib pajak bisa berupa wajib pajak orang pribadi atau wajib pajak badan. 


\section{Published December 2018}

\section{EKONOMIKAWAN : Jurnal Ilmu Ekonomi dan Studi Pembangunan}

ISSN : 1693-7600 (Print), ISSN : 2598-0157 (Online), http://jurnal.umsu.ac.id/index.php/ekawan

Peningkatan penerimaan Pajak Penghasilan (PPh) Pasal 21 dipengaruhi oleh Wajib pajak yang terdaftar dan SPT masa yang terlapor. Akan tetapi, pada kenyataannya Wajib Pajak terdaftar PPh Pasal 21 belum sepenuhnya memahami cara menghitung, membayar pajak kekas Negara dan melaporkannya kepada Kantor Pelayanan Pajak (KPP). Dan bahkan masih banyak Wajib Pajak terdaftar PPh Pasal 21 yang masih mengalami kesalahan dalam menghitung, membayar dan melaporkan kepada KPP bahkan ada juga yang belum mengerti undang undang perpajakan yang diterapkan.

\section{KAJIAN PUSTAKA}

\section{Pajak}

Berdasarkan UU Nomor 28 Tahun 2007 pasal 1 ayat 1 "Pajak adalah kontribusi wajib kepada Negara yang terutang oleh orang pribadi atau badan yang bersifat memaksa berdasarkan Undang Undang, dengan tidak mendapatkan imbalan secara langsung dan digunakan untuk keperluan Negara bagi sebesar besarnya kemakmuran rakyat."

Definisi pajak menurut Adriani yang dikemukakan dalam bukunya Waluyo (2009:2) yaitu: iuran pajak kepada negara (yang dapat dipaksakan) yang terhutang oleh wajib pajak, membayarnya menurut peraturan-peraturan, dengan tidak mendapatkan prestasi kembali, yang langsung dapat ditunjuk dan yang dapat digunakan untuk membiayai pengeluaranpengeluaran umum berhubungan dengan tugas negara untuk menyelenggarakan pemerintahan.

Bastari, dkk. (2015, hal. 1) menyatakan defenisi pajak menurut Djajadiningrat adalah sebaai berikut: "Pajak adalah kewajiban menyerahkan sebagian dari kekayaan kekas Negara yang disebabkan suatu keadaan, kejaduian, dan perbuatan yang memberikan kedudukan tertentu, tetapi bukan sebagai hukuman menurut peraturan yang ditetapkan pemerintah serta dapat dipaksakan, tetapi tidak ada jasa timbal balik dari Negara secara langsng, untuk memelihara kesehjateraan."

\section{Wajib Pajak}

Definisi Wajib Pajak Menurut UU Nomor 28 Tahun 2007 pasal 1, wajib pajak adalah orang pribadi atau badan, pembayar pajak, dan pemungut pajak, yang mempunyai hak dan kewajiban perpajakan sesuai dengan ketentuan peraturan perundang-undangan perpajakan.

Menurut UU No. 16 Tahun 2009 tentang Ketentuan Umum dan Tata Cara Perpajakan (UU KUP) pada pasal 1 ayat 2 Wajib Pajak adalah "Orang pribadi atau badan, meliputi pembayar pajak, pemotong pajak, dan pemungut pajak, yang mempunyai hak dan kewajiban perpajakan sesuai dengan ketentuan peraturan perundang undangan perpajakan". Dapat disimpulkan bahwa wajib pajak bisa merupakan orang pribadi atau bisa juga merupakan badan.

Menurut Undang-undang Nomor 16 Tahun 2009 hak dan kewajiban wajib pajak adalah :

1) Hak Wajib Pajak

a. Melaporkan beberapa masa pajak dalam satu Surat Pemberitahuan Masa

b. Mengajukan surat keberatan dan banding bagi wajib pajak dengan kriteria tertentu

c. Memperpanjang jangka waktu penyampaian Surat Pemberitahuan Tahunan Pajak Penghasilan untuk paling lama dua bulan dengan cara menyampaikan pemberitahuan secara tertulisatau dengan cara lain kepada Direktur Jenderal Pajak

d. Mengajukan permohonan pengembalian kelebihan pembayaran pajak 
Published December 2018

EKONOMIKAWAN : Jurnal Ilmu Ekonomi dan Studi Pembangunan

ISSN : 1693-7600 (Print), ISSN : 2598-0157 (Online), http://jurnal.umsu.ac.Id/index.php/ekawan

e. Mengajukan keberatan kepada Direktur Jenderal Pajak

f. Mengajukan permohonan banding kepada badan peradilan pajak atas Surat Keputusan Keberatan

g. Menunjuk seseorang kuasa dengan surat kasus untuk menjalankan hak dan memenuhi kewajiaban sesuai dengan ketentuan perundang-undangan perpajakan

h. Memperoleh pengurangan atau penghapusan sanksi administrasi berupa bunga atas keterlambatan pelunasan kekuragan pembayaran pajak

2) Kewajiban Wajib Pajak

a. Mendaftarkan diri untuk mendapatkan NPWP

b. Melaporkan usahanyabpada kantor Direktorat Jenderal Pajak yang wilayah kerjanya meliputi tempat tinggal atau tempat kedudukan pengusaha dan tempat kegiatan usaha dilakukan untuk dikukuhkan menjadi Pengusaha Kena Pajak

c. Mengisi SPT dengan benar, lengkap dan jelas

d. Menyampaikan SPT dalam bahasa Indonesia dengan menggunakan satuan mata uang selain rupiah yang diizinkan, yang pelakanaannya yang diatur dengan atau berdasarkan Peraturan Menteri Keuangan

e. Membayar atau menyetor pajak yang terutang dengan menggunakan Surat Setorsn Pajak ke Kas Negara melalui tempat pembayaran yang diatur dengan atau berdasarkan Peraturan Menteri Keuangan

f. Membayar pajak yang terhutang sesuai dengan ketentuan peraturan perundangundangan perpajakan.

\section{SPT Masa}

Menurut Mardiasmo (2009:29), Surat yang oleh Wajib Pajak digunakan untuk melaporkan perhitungan dan atau pembayaran pajak, objek pajak, dan atau bukan objek pajak dan atau harta dan kewajiban yang terhutang menurut ketentuan perundangundangan perpajakan.

Surat pemberitahuan (SPT) adalah surat oleh Wajib Pajak digunakan untuk melaporkan perhitungan dan/atau pembayaran pajak, objek pajak dan/atau bukan objek pajak, dan/atau harta dan kewajiban sesuai dengan ketentuan peraturan perundangundangan perpajakan Pasal 1, angka 11 Undang-undang Nomor 28 Tahun 2007 Tentang Ketentuan Umum Dan Tata Cara Perpajakan. Surat Pemberitahuan (SPT) Tahaunan dan Surat Pemberitahuan (SPT) Masa.

Menurut Suandy (2011:155) yang dimaksud dengan Surat Pemberitahuan (SPT) Masa adalah surat yang oleh wajib pajak digunakan untuk melaporkan perhitungan dan/atau pembayaran pajak yang terhutang dalam suatu masa pajak atau pada suatu saat. Menurut Mardiasmo (2011:32) Surat Pemberitahuan (SPT) Masa adalah surat pemberitahuan untuk suatu masa pajak atau pada suatu saat. Menurut Resmi (2014:43) Surat Pemberitahuan (SPT) Masa adalah surat pemberitahuan yang digunakan untuk melakukan pelaporan atas pembayaran pajak bulanan.

Dari beberapa definisi diatas dapat dinyatakan bahwa surat pemberitahuan (SPT) Masa adalah surat yang digunakan oleh wajib pajak untuk melaporkan perhitungan dan/ atau pembayaran pajak untuk masa pajak atau bulanan. Indicator dari surat pemberitahuan (SPT) Masa adalah Jumlah Wajib PPh Pasal 21 yang menyampaikan SPT Masa. 
Published December 2018

EKONOMIKAWAN : Jurnal Ilmu Ekonomi dan Studi Pembangunan

ISSN : 1693-7600 (Print), ISSN : 2598-0157 (Online), http://jurnal.umsu.ac.ld/index.php/ekawan

Fungsi Surat Pemberitahuan (SPT) menurut Mardiasmo (2011:29) yaitu :

1) Bagi Wajib Pajak Pajak Penghasilan adalah sebagai sarana untuk melaporkan dan mempertanggung jawabkan perhitungan jumlah pajak yang sebenarnya tentang dan untuk melaporkan tentang:

a. Pembayaran atau pelunasan pajak yang telah dilaksanakan sendiri dan/atau melalui pemotongan atau pemungutan pihak lain dalam 1 (satu) tahun pajak atau bagian tahun pajak:

b. Penghasilan yang merupakan objek pajak dan/atau bukan objek pajak;

c. Harta dan kewajiban; dan/atau

d. Pembayaran dari pemotongan atau pemungutan tentang pemotongan atau pemungutan pajak orang pribadi atau badan lain dalam 1 (satu) masa pajak sesuai ketentuan peraturan perundang-undangan perpajakan.

2) Bagi Pengusaha Kena Pajak, fungsi surat pemberitahuan adalah sebagai sarana untuk melaporkan dan mempertanggung jawabkan perhitungan jumlah Pajak Pertambahan Nilai dan Pajak Penjualan Atas Barang Mewah yang sebenarnya terhutang dan untuk melaporkan tentang:

a. Pengkreditan pajak masukan terhadap pajak keluaran; dan

b. Pembayaran atau pelunasan pajak yang telah dilaksanakan sendiri oleh Pengusaha Kena Pajak dan/atau melalaui pihak lain dalam satu masa pajak, sesuai dengan ketentuan peraturan perundang-undangan perpajakan.

3) Bagi pemotongan atau pemungutan pajak, fungsi surat pemberitahuan adalah sebagai sarana untuk melaporkan dan mempertanggung jawabkan pajak yang dipotong atau dipungut dan disetorkannya.

\section{Penerimaan Pajak Penghasilan PPh Pasal 21}

Pajak merupakan salah satu sumber penerimaan yang penting yang akan digunakan untuk membiayai pengeluaran baik rutin maupun pembangunan (Siti Resmi; 2011:3). Berdasarkan Undang-undang Nomor 19 Tahun 2012 tentang Anggaran Pendapatan Dan Belanja Negara, penerimaan perpajakan adalah semua penerimaan negara yang terdiri dari pajak dalam negeri dan pajak perdagangan internasional. Pajak dalam negeri adalah semua penerimaan negara yang berasal dari pajak penghasilan, pajak pertambahan nilai barang dan jasa dan pajak penjualan atas barang mewah, pajak bumi dan banguanan, bea perolehan ha katas tanah dan bangunan, cukai, dan pajak lainnya. Sedangkan pajak perdagangan internasional adalah semua penerimaan Negara yang berasal dari bea masuk dan bea keluar.

Berikut ini adalah beberapa definisi dari Pajak Penghasilan (PPh) Pasal 21. Menurut Mardiasmo (2011:192) Pajak Penghasilan (PPh) Pasal 21 adalah; "Pajak Penghasilan (PPh) Pasal 21 merupakan pajak pengahasilan yang dikenakan atas penghasilan berupa gaji, upah, honorarium, tunjangan, dan pembayaran lain dengan nama apapun sehubungan dengan pekerjaan, jasa, atau kegiatan yang dilakukan oleh Wajib Pajak orang pribadi dalam negeri."

Menurut Undang-Undang Nomor 36 Tahun 2008 Pajak Penghasilan (PPh) Pasal 21 adalah Penghasilan yang diperoleh Wajib Pajak orang pribadi berupa gaji, upah, honorarium, tunjangan dan pembayaran lain yang diterima sehubungan dengan pekerjaan atau jabatan, jasa dan kegiatan. 
Menurut Waluyo (2014:238) Pajak Penghasilan (PPh) Pasal 21 adalah "Pajak Penghasilan yang dikenakan atas penghasilan berupa gaji, upah, honorarium, tujangan, dan pembayaran lain dengan bentuk dan nama apa pun yang diterima atau diperoleh Wajib Pajak Orang Pribadi dalam negeri sehubungan dengan pekerjaan, jasa atau kegiatan tersebut yang dilakukan oleh Wajib Pajak Orang Pribadi dalam negeri."

Dari definisi diatas dapat dinyatakan bahwa Pajak Penghasilan Pasal $21(\mathrm{PPh}$ Pasal21) adalah Pajak Penghasilan yang diperoleh Wajib Pajak Orang Pribadi dalam negeri berupa gaji, upah, honorarium, tunjangan, dan pembayaran lain yang diterima sehubungan dnegan pekerjaan atau jabatan, jasa, dan kegiatan. Indikator Penerimaan Pajak Penghasilan Pasal 21 (PPh Pasal 21) adalah jumlah penerimaan Pajak Penghasilan Pasal 21 (PPh Pasal 21).

Objek Pajak Penghasilan Pasal 21 dalam Peraturan Menteri Keuangan Nomor 252/PMK.03/2008 adalah:

1) Penghasilan yang diterima atau diperoleh pegawai tetap, baik berupa penghasilan yang bersifat teratur maupun tidak teratur;

2) Penghasilan yang diterima atau diperoleh penerima pension secara teratur berupa uang pension atau penghasilannya sejenisnya;

3) Penghasilan sehubungan dengan pemutusan hubungan kerja dan penghasilan sehubungan dengan pension yang diterima secara sekaligus berupa uang pesangon, uang manfaat pensiun, tunjangan hari tua atau jaminan hari tua, dan pembayaran lain sejenis;

4) Penghasilan pegawai tidak tetap atau tenaga kerja lepas, berupa upah harian, upah mingguan, upah satuan, upah borongan, atau upah yang dibayarkan secara bulanan;

5) Imbalan kepada bukan pegawai, antara lain berupa honorarium, komisi, fee, dan imbalan sehubungan dengan pekerjaan, jasa, dan kegiatan yang dilakukan;

6) Imbalan kepada peserta kegiatan berupa uang saku, uang representasi, uang rapat, honorarium, hadiah atau penghargaan dengan nama dan dalam bentuk apa pun, dan imbalan sejenis dengan nama apa pun;

7) Penerimaan dalam bentuk natura dan/atau kenikmatan lainnya dengan nama dan dalam bentuk apa pun yang diberikan oleh:

a. Bukan wajib pajak;

b. Wajib pajak yang dikenakan pajak penghasilan yang bersifat final; atau

c. Wajib pajak yang dikenakan pajak penghasilan berdasarkan norma perhitungan khusus (deemed profit)

\section{Kerangka Berpikir}

Kerangka berpikir merupakan unsur-unsur pokok dalam penelitian yang dapat menggambarkan rangkaian variabel yang akan diteliti dan dapat dijelaskan sebagai berikut:

Kewajiban Wajib Pajak seperti melaksanakan perhitungan, menyetor, dan melaporkan sendiri pajak yang terutang. Sehingga dengan semakin banyak jumlah Wajib Pajak PPh Badan yang terdaftar pada Kantor Pelayanan Pajak Pratama Belawan, maka jumlah wajib pajak yang menyetor pembayaran PPh Pasal 21 akan semakin banyak, akhirnya penerimaan PPh Pasal 21 Orang Pribadi juga akan meningkat. 
Dalam penyampaian SPT Masa sangat menentukan tercapainya realisasi penerimaan pajak penghasilan $(\mathrm{PPh})$ pasal 21. Sedangkan agar pemotongan, penyetoran, dan pelaporan pajak atas penghasilan wajib pajak dapat dilakukan sebaik-baiknya, maka perlu ditetapkan ketentuan mengenai pelaksanaan pemotongan, penyetoran, dan pelaporan pajak penghasilan $(\mathrm{PPh})$, khususnya pajak penghasilan $(\mathrm{PPh})$ pasa 21. (Iprianto dan Tarmidi : 2014)

Surat Pemberitahuan (SPT) tidak hanya berfungsi sebagai data melainkan sarana komunikasi antara Wajib Pajak dengan Fiskus untuk mempertanggung jawabkan pemenuhan seluruh kewajiban perpajakan perusahaan selama waktu tertentu. Dan diharapkan Surat Pemberitahuan dapat meningkatkan penerimaan pajak.

Untuk memperbaiki masalah pada penerimaan pajak penghasilan pasal 21 dapat dilakukan dengan adanya peningkatan pengawasan mengenai penyampaian surat pemberitahuan (SPT) masa dan juga dapat dilakukan dengan meningkatkan jumlah wajib pajak efektif yaitu dengan cara lebih meningkatkan lagi sosialisasi atau pengarahan dengan cara mengumpulkan semua wajib pajak tentang pentingnya kesadaran para wajib pajak untuk membayar kewajiban perpajakannya sesuai dengan ketentuan perundang-undangan yang berlaku.

\section{METODE}

Pendekatan penelitian ini adalah pendekatan deskriptif, yaitu suatu metode analisis dengan cara mendeskripsikan atau menggambarkan data yang telah terkumpul sehingga dapat memberikan kesimpulan mengenai penyampaian SPT Masa dan jumlah wajib pajak badan dalam meningkatkan penerimaan pajak penghasilan pasal 21.

\section{HASIL DAN PEMBAHASAN}

\section{Penyebab Penerimaan Pajak Menurun Sedangkan Wajib Pajak dan SPT Masa Meningkat}

Dalam hal ini ada beberapa faktor yang menghambat penerimaan pajak meningkat sedangkan wajib pajak badan dan SPT Masa yang disampaikan meningkat walaupun kurang signifikan yaitu:

a. Rendahnya tingkat kesadaran wajib pajak badan dalam melaksanakan kewajiban perpajakannya yaitu menyampaikan SPT masa sehingga wajib pajak badan tidak sebanding dengan Wajib pajak badan yang menyampaikan SPT Masa.

b. Ketidak tepatan waktu dalam memyampaikan SPT Masa. Wajib pajak sering membayar pajaknya dan menyampaikan SPT Masa tidak sesuai dengan waktu yang telah ditetapkan sehingga berpengaruh terhadap jumlah penerimaan nantinya.

c. Perubahan Penghasilan Tidak Kena Pajak (PTKP) yang semakin besar mengakibatkan penerimaan pajak menurun jika tidak diikuti dengan peningkatan gaji atau upah yang diterima.

d. Adanya Pemutusan Hubungan Kerja (PHK) yang terjadi di dalam perusahaan sehingga mengakibatkan rendahnya wajib pajak dalam menyampaikan SPT Masa dan membayar pajak, sehingga hal ini mengakibatkan penerimaan pajak yang menurun dan tidak mencapai target yang telah ditetapkan.

e. Kurangnya sosialisasi yang dilakukan pihak fiskus kepada wajib pajak mengenai pentingnya melaksanakan kewajiban perpajakan. 
f. Rendahnya tingkat pengetahuan wajib pajak mengenai undang-undang perpajakan, dimana wajib pajak kurang memahami mengenai system administrasi yang ada secara tidak langsung dapat menghambat bagian administrasi perpajakan dalam menyampaikan SPT nya seperti tidak memahami bagaimana cara menghitung, memperhitungkan dan Melaporkan SPT nya.

g. Faktor ekonomi. Dapat dilihat dari perkembangan ekonomi saat ini masih belum baik sehingga berpengaruh terhadap perekonomian wajib pajak badan dimana rendahnya saat ini. Dengan adanya factor ekonomi yang rendah menyebabkan penerimaan yang seharusnya diterima oleh KPP Pratama Medan Belawan tidak teralisasikan, sehingga penerimaan yang diperoleh tidak mencapai target yang telah ditetapkan oleh KPP Pratama Medan Belawan.

\section{Bagaimana penyampaian SPT Masa dan jumlah wajib pajak badan dalam meningkatkan penerimaan pajak penghasilan pasal 21?}

Penyampaian SPT Masa dan Jumlah wajib pajak badan di KPP Pratama Medan Belawan belum menunjukkan hasil yang maksimal dan belum dapat meningkatkan penerimaan pajak, hal ini dikarenakan masih banyaknya wajib pajak yang belum menyampaikan SPT Masa, kurangnya pengetahuan perpajakan dan masih lemahnya pengawasan dari fiskus (petugas pajak) terhadap wajib pajak badan.

Hasil penelitian ini sesuai dengan penelitian Monita Pantreysih Dauhan, David Paul Ella Saerang, Robert Lambey yang mengemukakan bahwa "Pada tahun 2013 realisasi belum mencapai target dikarenakan adanya wajib pajak badan yang melalaikan kewajiban dalam membayar pajak, kurangnya pengetahuan tentang perpajakan dan kurangnya sosialisasi di KPP Pratama Bandung"

Adapun upaya-upaya yang dapat dilakukan agar realisasi pajak dapat mencapai target pajak yang telah ditetapkan di KPP Pratama Medan Belawan yaitu sebagai berikut:

a. Lebih ditingkatkan lagi sosialisasi dalam pembinaan terhadap wajib pajak mengenai pentingnya melaksanakan kewajiban perpajakan sesuai dengan undang-undang perpajakan.

b. Lebih tegas terhadap wajib pajak yang enggan melaksanakan kewajiban perpajakannya.

c. Penerapan sanksi perpajakan baik administrasi (denda, bunga dan kenaikan) dan pidana (penjara) mendorong kepatuhan wajib pajak dalam melaksanakan kewajiban perpajakannya.

d. Lebih ditingkatkan lagi pengawasan yang dilakukan fiskus (petugas pajak) terhadap wajib pajak.

e. Lebih ditingkatkan lagi kualitas fiskus (petugas pajak) dalam pelaksanaan peraturan perundang-undangan perpajakan.

\section{SIMPULAN}

Wajib pajak yang menyampaikan SPT Masa belun menujukkan keseimbangan dengan wajib pajak yang terdaftar setiap tahunnya sehingga menyebakan realisasi pajak cenderung mengalami penurunan dan tidak mencapai target yang telah ditetapkan. Faktor penyebab realisasi pajak tidak mencapai target pajak adalah berasal dari wajib pajak dan fiskus (petugas pajak) yaitu wajib pajak yang kurang kesadaran dalam melaksanakan kewajiban perpajakannya dan fiksus yang kurang meningkatkan lagi pengawasan terhadap wajib pajak. 


\section{DAFTAR PUSTAKA}

Arfan Ikhsan, dkk. 2014. Metodologi Penelitian Bisnis. Citapustaka Media, Medan. Bastari, dkk. 2015. Perpajakan : Teori dan Kasus. Perdana Publishing, Medan.

Diaz Priantara. 2016. Perpajakan Indonesia, Edisi 3. Mitra Wacana Media, Jakarta.

Erly Suandy. 2011. Perencanaan Pajak, Edisi 5. Selemba Empat, Jakarta.

Harjo Dwikora. 2013. Perpajakan Indonesia. Mitra Wacana Media, Jakarta.

Ilyas B. Wirawan dan Rudy Suhartono. 2013. Perpajakan. Jakarta: Mitra Wacana Media. Iprianto dan Tarmidi. 2014. Pengaruh Tidak Ketidaktepatan Penyampaian Surat Pemberitahuan (SPT) Masa Terhadap Penerimaan Pajak Penghasilan (PPh) Pasal

21 Pada KPP Pratama Bengkulu. Bengkulu: Jurnal Akuisisi Univeristas Muhammadiyah Metro. Vol.10, No 2.

Mardiasmo. 2009. Perpajakan (edisi revisi). Andi, Yogyakarta 2011. Perpajakan (edisi revisi). Andi, Yogyakarta.

Monita Pantreysih Dauhan, David Paul Ella Saerang, Robert Lambey. 2015. Analisis Kepatuhan Wajib Pajak Badan Berdasarkan Realisasi Penerimaan Pajak Penghasilan Badan (Studi Kasus Pada KPP Kota Bitung). Bitung: Jurnal Berkala Ilmiah Efesiensi. Vol 15 No. 04.

Pardiat. 2007. Pemeriksaan Pajak. Mitra Wacana Media, Jakarta.

Regina Noor. 2015. Pengaruh Penyampaian SPT Masa dan Jumlah Wajib Pajak Terhadap Penerimaan Pajak Penghasilan Pasal 21 (PPh 21) (Studi Kasus Pada KPP Pratama Bandung Karees 2013-2015). Jurnal Ekonomi dan Bisnis, Bandung.

Rosalina Pebrica Mayasari, Ucu Permata Sari. 2015. Pengaruh Jumlah Wajib Pajak Terdaftar dan Jumlah SPT terlapor Terhadap Penerimaan Pajak Penghasilan Pasal 21 Pada KPP Pratama Palembang Ilir Barat. Palembang: Jurnal Ilmiah Ekonomi Global Masa Kini. Vol.06 No.01.

Siti Resmi. 2011. Perpajakan: Teori dan Kasus. Selemba Empat, Jakarta. . 2014. Perpajakan: Teori dan Kasus. Selemba Empat, Jakarta.

Waluyo. 2009. Perpajakan Indonesia. Selemba Empat, Jakarta.

2011. Perpajakan Indonesia. Selemba Empat, Jakarta.

2014. Perpajakan Indonesia. Selemba Empat, Jakarta.

Undang-Undang Perpajakan Nomor 28 Tahun 2007 Tentang Ketentuan Umum dan Tata Cara Perpajakan (UU KUP).

Undang-Undang Perpajakan Nomor 16 Tahun 2009 Tentang Ketentuan Umum dan Tata Cara Perpajakan (UU KUP).

Undang-Undang Republik Indonesia Nomor 19 Tahun 2012 Tentang Anggaran Pendapatan Dan Belanja Negara.

Undang-Undang Perpajakan Nomor 36 Tahun 2008 Tentang Pajak Penghasilan.

Peraturan Menteri Keuangan Nomor 252/PMK.03/2008.

www.pajak.go.id 